\title{
GAPURA SEBAGAI DESAIN KOMUNIKASI VISUAL TENUN TROSO KABUPATEN JEPARA
}

\author{
${ }^{1}$ Kukuh Dwi Wijanarko, ${ }^{2}$ Nanang Rizali, ${ }^{3}$ Ahmad Adib \\ ${ }^{1}$ Mahasiswa Pasca Sarjana Seni Rupa, ${ }^{2}$ Dosen Kriya Tekstil Universitas Sebelas Maret Surakarta \\ ${ }^{3}$ Dosen DKV FSRD Universitas Sebelas Maret Surakarta \\ Universitas Sebelas Maret Surakarta \\ kukuhdwijan@student.uns.ac.id
}

\begin{abstract}
Gapura as the entrance to tourist sites Troso weaving is very important, because it is a symbol of visual communication design at the forefront of the village entrance. In general, the purpose of this study to find answers that fit with the main problem is how the gate can visualize the concept of brand visual communication to give impact to the development of Troso Jepara Weaving. The research method is descriptive, that is to make an accurate, systematic and factual explanation about the facts and nature of the population or specific location in this sense in research. The Troso weaving gate was originally established in 2012 and was inaugurated by the district governance of Jepara. Prospects after the gate of Troso Weaving can be seen on the Propinsi road from Semarang to downtown Jepara, it is expected that many people come to Troso village, so that entrepreneurs can market directly to buyers without third party intermediaries..
\end{abstract}

Keywords: Archway, Design, Communication and Visual.

Relevance to Visual Communication Design Practice: Gapura should be able to describe the concept of visual communication, thus giving impact to the development of Troso Jepara woven fabric.

\section{PENDAHULUAN}

\section{Latar Belakang}

Pengembangan ekonomi lokal merupakan penumbuhan suatu lokalitas secara lebih mandiri dengan menggunakan potensi kekuatan lokal, sumber daya manusia, kelembagaan dan fisik dengan upaya yang ditumbuhkembangkan masyarakat lokal, (World Bank, 2001:35). Pengembangan ekonomi lokal menyediakan cukup banyak alternatif program atau kegiatan yang dapat dipilih sebagai prioritas dalam mendorong pengembangan ekonomi lokal di daerah salah satunya mendorong pertumbuhan klaster usaha.

Hasil penelitian (Muchamad,dkk, 2014:11), indusrti rokok kretek yang kuat di kabupaten Kudus dan berbagai potensi pariwisata yang dapat dikembangkan seperti sektor pariwisata, sejarah, religius, dan budaya yang disatukan dalam visual branding kota Kudus untuk membentuk identitas guna menarik wisatawan, investor dan menbendakan kompetitor. Penelitian (Adityo, 2013:18) dalam membranding kota Solo, perlu adanya sinergi dengan biro advertising, sales promotion, dan public relations agar media promosi lebih banyak dan upaya branding Kota Solo mampu memotivasi target audience untuk berkunjung dan merekomendasikan Solo sebagai destinasi wisata maupun tempat tinggal. Strategi komunikasi pemasaran yang dinamis dibutuhkan untuk setiap event kebudayaan untuk menghasilkan jumlah kunjungan 
wisatawan yang maksimal. Penggunaan media promosi kontemporer seperti pengadaan website Kota Solo, pnggunaan jejaring sosial facebook dan twitter dalam mempromosikan kebudayaan Kota Solo. Penciptaan image dan brand awareness Destinasi Wisata Lovina ditentukan oleh marketing komunikasi organisasi dan khalayak internal. Khalayak internal terdiri dari nelayan setempat, karyawan hotel yang merangkap sebagai nakoda kapal dan masyarakat petani yang juga berprofesi di sawah di pagi hari dan menjadi stake holder sekaligus masyarakat lokal. Keterlibatan mereka dalam aktivitas marketing komunikasi, akan memberi dampak positif terhadap ekonomi, social dan lingkungan masyarakat. Hal ini akan menjamin terjadinya pariwisata yang keberlanjutan (Karta dan Suarthana, 2014:50).

Troso, dikenal sebagai Kampung Tenun, karena di Troso terdapat banyak toko kain Tenun. Banyak masyarakat yang berbondong-bondong ke desa Troso untuk mendapat kain tenun berkualitas dengan harga yang kompetitif. Tercatat ada 628 UMKM kain tenun yang telah beroperasi di sekitar Kota Troso (BPS Kab. Jepara, 2017:36). Brand Troso telah terbentuk, publik yang mendengar desa Troso, maka yang diingatnya dan yang ada di dalam benaknya adalah tempat tenun ikat. Troso mampu membentuk persepsi publik dalam mengenali, mengingat kembali suatu merek sebagai bagian dari suatu kategori produk tertentu. Bagian dari suatu kategori produk perlu ditekankan karena terdapat suatu hubungan yang kuat antara kategori produk dengan merek yang dilibatkan melalui Brand Awareness.
Branding Tenun Troso sangat penting, karena kain Troso sebagai tekstil yang dapat mencerminkan status seseorang dalam masyarakat. Tekstil dapat berperan sebagai alat pelindung dan kebutuhan pokok sesuai dengan perkembangan zaman juga berfungsi untuk kepentingan yang lainnya yaitu komunikasi, atau identitas, pakaian berperan untuk menambah keindahan pemakai (Rizali, 2014:196). Kain Troso sejak zaman Presiden SBY, sering dipakai dalam berbagai acara kenegaraan, hingga tercipta motif SBY di Troso serta Motif Obama, karena pernah dipakai presiden Barrack Obama saat berkunjung ke Indonesia. Status kain Troso yang memiliki keindahan dan seringkali dipakai orang terkenal ini perlu dipromosikan dengan branding yang baik. Permasalahan utama kain Troso adalah selain harganya lebih mahal dari kain yang lain, promosi untuk membranding Troso juga sangat kurang. Visual Brand tenun Troso di Kabupaten Jepara banyak ditampilkan melalui showroom sebagai setrategi komunikasi para pengusaha dengan kekhasan masing-masing perusahaan dengan harapan dapat menarik minat wisatawan untuk membeli tenun. Keinginan pengusaha Troso untuk lebih dikenal luas, tidak hanya melalui penghargaan seremonial, akan tetapi bagaimana tenun Troso dapat lebih diminati masyarakat Indonesia dan dunia sebagai tekstil khas karya kreatif warga masyarakat Troso Jepara dengan nilai kebudayaan yang tinggi.

Gapura sebagai pintu masuk ke lokasi wisata Tenun Troso sangat penting, karena merupakan simbol desain komunikasi visual di lokasi terdepan pintu masuk desa. Secara umum tujuan penelitian ini untuk mencari 
jawaban yang sesuai dengan permasalahan utama yaitu bagaimana gapura dapat memvisualkan konsep komunikasi visual brand sehingga memberi dampak terhadap perkembangan Tenun Troso Jepara.

\section{TEORI}

\section{Desain}

Kata desain dapat diuraikan sebagai berikut, desain merupakan suatu kerangka bentuk, rancangan (Hasan, 2002: 25), yang dibuat dengan sebaik mungkin yang nantinya dapat menginformasikan pesan kepada sasaran secara maksimal dan menarik. Sedangkan pada buku Enseklopedia Nasional Indonesia desain berasal dari kata latin Designore, yang secara umum berarti sketsa atau rencana suatu karya seni, gedung ataupun mesin yang akan dibuat. Desain dapat juga dikatakan kombinasi detail dan bentuk suatu gambar, bangunan atau jembatan, pola benda yang direncanakan secara artistik.

Secara etemologis desain berasal dari kata designo (italia) yang artinya gambar (Sachari, 2004:4) Keputusan pertama dalam desain adalah menentukan bentuk, ukuran dan proporsi area desain dalam hal ini berkaitan dengan pemilihan media, Pemilihan media yang tepat dan efektif gunanya untuk mencapai sasaran yang dituju (Kusmiati, 1999: 126). Penggunaan bahan kertas sebagai bahan baku turut menentukan bentuk fisik dalam mengeksekusi konsep kreatif.

\section{Komunikasi Massa/ Public Relation}

Public Relations Ini memperlihatkan bahwa suatu pendekatan manajemen perlu direncanakan dalam kepada target-target masyarakat tertentu. Kegiatan PR ini menggunakan dengan cara membujuk kepada saasaran khalayak (Kasali, 2007:34). Aktivitas praktisi Public Relations di lapangan praktik yaitu sejauh mana kemampuannya untuk berperan sebagai pendengar (listener), penasehat (counselor), komunikator (communicator), dan penilai (evaluator) yang handal. Oleh karena itu menjadi sangat penting apabila pejabat Public Relations melihat kemampuannya dalam memecahkan berbagai macam persoalan-persoalan yang dihadapi. Masyarakat menjadi bagian terpenting dari organisasi, karena eksistensi organisasi banyak sekali dipengaruhi oleh kelanggengan hubungan antara organisasi dengan masyarakat. Hal yang sama juga diutarakan oleh Rhenald Kasali dalam bukunya "Manajemen Public Relations" bahwa:"Untuk menjalankan tugasnya, Public Relations perlu memahami sikap dan perilaku masyarakatnya dengan memahami sungguh-sungguh latar belakang dari sikap tersebut. Mengidentifikasi siapa publiknya, apa bentuk dan sekmentasi publik, akan mengefektifkan peran Public Relations. Identifikasi ini memberi petunjuk:siapa publik yang aktif dan siapa yang pasif. Dari situ Public Relations dapat mengarahkan kegiatan komunikasinya" (Kasali, 2007:55).

\section{Visual}

Desain komunikasi visual adalah ilmu yang mempelajari konsep komunikasi dan ungkapan daya kreatif, yang diaplikasikan dalam berbagai media visual dengan mengolah elemen-elemen perupaan. Desain komunikasi visual digunakan untuk menyampaikan pesan secara visual. Desain 
komunikasi visual dalam pengertian modern adalah desain yang dihasilkan dari rasionalitas (Widagdo, 1993:31).

Definisi Desain Komunikasi Visual adalah ilmu yang mempelajari konsep komunikasi dan ungkapan kreatif, teknik dan media untuk menyampaikan pesan dan gagasan secara visual, termasuk audio dengan mengolah elemen desain grafis berupa bentuk gambar, huruf dan warna, serta tata letaknya, sehingga pesan dan gagasan dapat diterima oleh sasarannya. Pesan visual harus kreatif (asli, inovatif dan lancar), komunikatif, efisien dan efektif, sekaligus indah/estetis. Berbeda dengan prinsip desain grafis. Dalam ilmu desain grafis, selain prinsip-prinsip diatas ada beberapa prinsip utama komunikasi visual dari sebuah karya desain.

\section{METODOLOGI}

\section{Pendekatan Penelitian}

Dalam penelitian tersebut nantinya pendekatan yang digunakan dalam penelitian ini adalah pendekatan deskriptif kualitatif yaitu pendekatan yang digunakan karena pertimbangan pendekatan ini bersifat fleksibel, tidak kaku,tidak lazim mengidentifikasi suatu konsep, serta memberikan kemungkinan bagi perubahanperubahan manakala ditemukan fakta-fakta yang mendasar, menarik, unik, dan bermakna di lapangan.

Jenis penelitian ini adalah penelitian deskriptif. Penelitian deskriptif adalah penelitian yang dilakukan untuk mengetahui nilai variabel mandiri baik satu variabel atau lebih (independent) tanpa membuat perbandingan atau menghubungkan antara variabel satu dengan variabel yang lain
(Sugiyono, 2009:38). Pendapat lain mengatakan bahwa penelitian deskriptif merupakan penelitian yang dimaksudkan untuk mengumpulkan informasi mengenai status suatu gejala yang ada yaitu keadaan gejala menurut apa adanya pada saat penelitian dilakukan (Arikunto, 2005:54).

Kesimpulannya tujuan dari penelitian deskriptif adalah untuk membuat penjelasan secara akurat, sistematis dan faktual mengenai fakta-fakta dan sifat populasi atau lokasi tertentu dalam arti ini pada riset.

\section{Metode Pengumpulan Data}

Dalam penelitian ini teknik yang digunakan adalah sebagai berikut:

\section{Survei lapangan/ Observasi}

Teknik ini sesuai untuk pengumpulan data primer dengan cara langsung melakukan pengamatan di lapangan untuk digabungkan dan dilengkapi data yang didapatkan dari data skunder. Secara visual pengamatan biasanya dilengkapi dengan kamera dan catatan lapangan. Observasi pertama yang dilakukan adalah mengunjungi balai desa Troso untuk mengetahui keadaan administrasi desa Troso serta mencari data pengusaha dan Cluster atas informasi dari perangkat desa Troso. Selanjutnya observasi dilakukan untuk mengunjungi beberapa perusahaan Troso serta cluster yang tergabung dalam koperasi paguyuban pengusaha tenun Troso.

\section{Wawancara Ahli}

Interview yaitu teknik pengumpulan data dengan cara mengadakan tanya jawab langsung kepada orang yang dianggap dapat memberikan data-data 
yang dibutuhkan. Wawancara dilakukan untuk mendapatkan informasi dari informan atau orang yang dianggap mengetahui tentang hal tersebut. Informan ditentukan dengan purposive snowball sampling. Teknik ini pada awalnya ditentukan sejumlah kecil orang kemudian akan berkembang sesuai dengan kebutuhan data sehingga data yang dikumpulkan lengkap sesuai dengan tujuan penelitian. Wawancara dilakukan di desa Troso kepada informan yang mengetahui permasalahan penelitian terutama kepada Petinggi, Pengurus Cluster, Pengusaha tenun Troso dan Tokoh Masyarakat.

\section{Studi Arsip/ Dokumentasi}

Teknik ini sesuai untuk pengumpulan data skunder yang dikumpulkan dari instansi atau lembaga-lembaga yang berkompeten, berupa laporan-laporan, jurnal, artikel media dan lain lain yang dipandang relevan dengan penelitian yang dilakukan. Dokumentasi yang utama adalah foto perusahaan serta screenshot beberapa website para pengusaha tenun Troso. Selain itu dokumentasi juga mengumpulkan foto dari screenshot sosial media yang digunakan masyarakat sebagai komunitas untuk mengkomunikasikan wisata tenun Troso.

\section{Metode Analisis Data}

Metode yang digunakan untuk mengumpulkan data dalam penelitian ini adalah wawancara semi terstruktur (semistructured interviews) Wawancara semi terstruktur (semi-structured interviews) menurut Greener (2008:34) adalah wawancara yang didasarkan pada panduan pertanyaan, yang isinya akan selalu menanyakan kepada responden. Namun, karena hal ini tidak sepenuhnya terstruktur, maka peneliti diperbolehkan untuk mengalihkan pertanyaan ke hal-hal lain yang menarik perhatian. Karena fokus wawancara kualitatif adalah pada yang diwawancarai, bukan pewawancara.

Sebagaimana yang dikemukakan (Moleong, 2005:35) apabila data yang diperoleh dari beberapa sumber, teknik triangulasi yang paling tepat dipakai adalah triangulasi sumber atau pemeriksaan data melalui sumber lain. Hal ini dapat dicapai melalui beberapa cara diantaranya adalah:

1. Membandingkan data hasil pengamatan dengan data hasil wawancara.

2. Membandingkan keadaan dan perspektif seseorang dengan berbagai pendapat orang.

3. Membandingkan hasil wawancara dengan dokumentasi.

\section{PEMBAHASAN}

\section{Keberadaan Gapura Tenun Di Desa Troso}

Jepara

Gapura Tenun Troso berada desa Pecangaan Kulon, arah masuk Desa Troso Kecamatan Pecangaan Kaupaten Jepara sebagai jalan masuk sentra kerajinan Tenun Ikat dan merupakan produk unggulan Kabupaten Jepara setelah industri mebel. Desa Troso terletak sekitar $15 \mathrm{Km}$ arah Tenggara Kota Jepara. Banyaknya pengerajin yang berkebang saat ini mennjadikan Troso semakin dikenal luas sebagai clastre home industry kain ATBM (alat tenun bujkan mesin). Sesuai dengan perkembangan pasar, permintaan 
terhadap produk Tenun Ikat Troso pun semakin berkembang mengikuti permintaan konsumen. Motif khas yang bernuansa etnis, tradisional, klasik, dan unik pun masih dipertahankan disamping motif kontemporer modern. Produk yang dihasilkan antara lain Kain Sutra, Sajadah, Bed Cover, Blangket, Sarung, Kain, Mersis (bahan Baju dan Rok), Place met, Taplak Meja dan produk-produk menarik lainnya. Perkembangan industri tenun ini telah mencapai 238 unit usaha dan meyerap tenaga keja sebanyak 4.210 orang pada tahun 2005 dengan nilai investasi lebih dari Rp. 1 Milyar. Produksi hingga saat ini telah mencapai sekitar Rp. 54,5 Milyar.

Industri tenun Troso menghabiskan bahan baku sekitar 1.326 ton per tahun dengan nilai bahan baku sekitar Rp. 65,2 Milyar. Bahan baku yang sering dipakai antara lain katun, viskos, sutra alam, serat nanas, rayon,pewarna, rafia. Permasalahan saat ini adalah terbatasnya ketersediaan bahan baku terutama sutra alam. Keterampilan membuat Tenun Ikat sudah dimiliki oleh warga Desa Troso sejak tahun 1935, jauh sebelum kemerdekaan RI. Bermula dari alat Tenun Gedog warisan turun-temurun kemudian sekitar tahun 1943 mulai berkembang alat Tenun Pancal dan kemudian pada tahun 1946 beralih menjadi Alat Tenun Bukan Mesin (ATMB) hingga sekarang. Setelah Tenun Troso berkembang serta menjanjikan prospek yang cerah bagi para pengerajin dan pengusaha, Tenun kemudian bukan hanya menjadi monopoli masyarakat Desa Troso, tetapi juga mulai merambah desa sekitarnya, yaitu Desa Sowan Lor dan Desa Pecangaan Kulon, sehingga produksi bahan sandang ini semakin meningkat. Apalagi masuknya inovasi baru berupa desaindesain baru dari perancang mode yang mudah diserap oleh para pengrajin,membuat Tenun Troso melejit mengungguli tenun ikat daerah lain. Namun sebelum sampai kondisi seperti sekarang ini, dalam setiap kesempatan para pengusaha Tenun Troso senantiasa diajak dan didorong untuk mengikuti berbagai macam pameran, baik yang dilakukan didalam maupu diluar negeri. Setelah serangkaian pameran yang disertai upaya peningkatan kualitas sesuai dengan permintaan pasar, industri ini semakin dikenal, bukan saja didalam negeri tetapi telah mulai menyibak pintu pasar internasional.

Pada kain tenun Troso Jepara ini tidak terlepas dengan ragam hias di dalamnya ini tentu saja berhubungan dengan motif. Motif adalah merupakan bagian dari satu kesatuan ragam hias atau ornamen. Berkenaan dengan seni kerajinan tenun, maka yang dimaksud dengan ornamen pada sebuah kain tenun adalah susunan motif hias kain tenun yang berfungsi untuk menambah keindahan bentuk atau wujud dari kain tenun itu sendiri. Ragam motif kain tenun Troso Jepara ini selalu mengalami perubahan. Hal tersebut terjadi karena para perajin tenun Troso Jepara Lebih mementingkan aspek dagang daripada aspek budaya. Pada awal munculnya motif kain tenun Troso pertama kali adalah motif Lurik yang hiasnya berupa garis-garis dan polos. Namun belakangan para perajin dan pengusaha tenun membuat motif tenun sesuai permintaan pesanan. Dominasi warna-warna pada kain tenun Troso ini 
adalah warna-warna klasik dan gelap seperti coklat muda/ tua, biru tua.

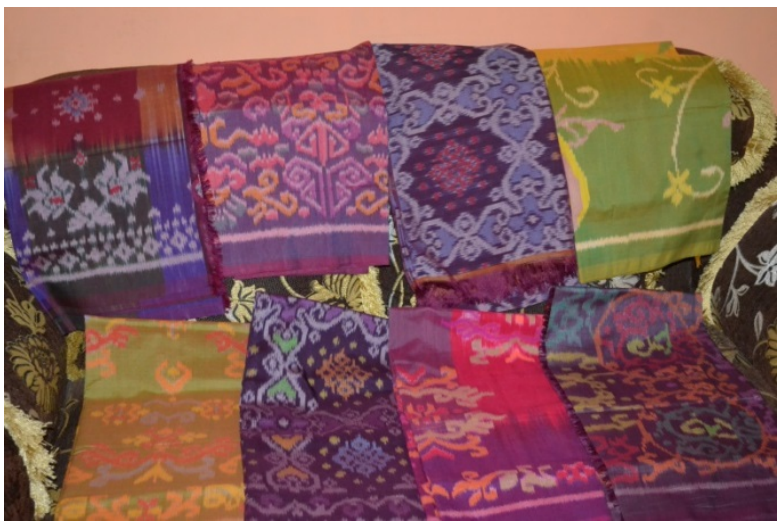

Gambar 1 Motif dan warna Tenun Troso Jepara Sumber: Wijanarko (6/7/2017)

Secara sistematis proses produksi Perusahaan Tenun Ikat Troso Jepara yang pertama adalah persiapan, yaitu mempersiapkan bahan baku yang berupa benang pakan dan benang lusi. Langkah selanjutnya pencelupan dan pewarnaan yaitu pewarnaan benang pakan dan lusi. Setelah proses pewarnaan terdapat perbedaan proses antara benang lusi dan pakan sebelum ditenun. Benang lusi sebelum diproses ke penenunan harus melalui proses palet, penghanian dan pencucukan, sedangkan untuk benang pakan hanya dipalet dan kemudian masuk ke proses penenunan. Setelah proses penenunan maka proses selanjutnya adalah finishing.

Adaptasi ekonomi dapat dipandang sebagai suatu upaya masyarakat dalam rangka mengembangkan dan mempertahankan sistem perekonomiannya. Melalui kegiatan bertenun ikat tersebut, adaptasi ekonomi yang dilakukan masyarakat Troso dapat dipandang sebagai upaya yang dilakukan masyarakat Troso dalam rangka mengembangkan dan mempertahankan kegiatan ini sebagai bentuk mata pencahariannya. Berbagai faktor telah menyebabkan tumbuh-kembangnya kegiatan ini di desa Troso. Namun upaya masyarakat tersebut kini semakin terlihat dengan semakin terikatnya kegiatan ini dengan situasi pasar yang lebih luas. Hal ini menandai keterbukaan masyarakat yang lebih besar terhadap situasi perdagangan bebas, artinya bahwa masuknya unsur-unsur eksternal tersebut telah mewarnai sistem perekonomiannya menjadi semakin kompleks. Pada dasarnya sistem perekonomian masyarakat di pedesaan senantiasa akan terkait dengan sistem hubungan sosial yang berlaku, artinya ruang geraknya akan dibatasi oleh unsur internal tersebut. Karena itu keputusan-keputusan masyarakat menyesuaikan diri terhadap faktor eksternal dapat dipandang sebagai suatu bentuk mekanisme perubahan. Dalam hal ini unsur-unsur internalnya tidak dapat sepenuhnya terlepas, namun diwarnai oleh unsur- unsur eksternal telah menyebabkan munculnya bentuk sistem perekonomian yang semakin kompleks.

Di Troso ini kira-kira terdapat 383 pengusaha atau pengrajin. Alat ATBM-nya kurang lebih berjumlah 5.000 unit. Sedangkan tenaga kerja yang terserap kurang lebih ada 7.500 orang. Tenaga kerja yang diserap oleh perusahaan tenun ini dilakukan secara gethok tular, informasi diperoleh dari mulut ke mulut. Pada umumnya tenaga kerja berasal dari Demak, Pati, Jepara, Rembang, Pekalongan, Pemalang, Tegal, dan Lasem. Biasanya mereka bekerja di industri tenun Troso karena ada saudaranya atau tetangganya yang pernah bekerja di sini, sehingga mereka tertarik untuk melakukannya juga. 
Tumbuhnya industri kerajinan rumahan di Troso, ternyata membawa dampak posisitif bagi masyarakat sekitarnya. Yang terjadi bukannya persaingan antar pengrajin yang umumnya penduduk asli setempat, tetapi bagaimana tetap menjalankan roda usaha dengan dukungan tenaga kerja yang makin sulit dicari. Pada tahun 2016, Tenun Hidayah mengoperasikan 100 unit alat tenun bukan mesin (ATBM) serta 2 unit alat tenun mesin yang dalam seminggu memiliki perputaran omzet sampai sekitar Rp. 30.000.000,-. Dampak positif dari tumbuhnya industri rumahan di Troso, bukan hanya terjadi di sektor ekonomi. Tetapi juga pada sektor-sektor lainnya, seperti tumbuhnya industri rumahan di Troso, maka sulit ditemukan pemuda atau remaja yang tidak bersekolah menganggur. Bahkan dalam sektor keamanan, juga terjadi penurunan angka kriminalitas secara drastis.

Setelah adanya Gapura desa Troso, Menurut H. Sairin maupun Bapak Bukhori, prospek industri kerajinan tenun cukup cerah. Dengan modal awal Rp. 1.000.000,mereka sudah dapat memulai usaha dengan membeli alat dan benang. Adapun sistem pemasarannya biasanya cukup sederhana. Setelah memiliki beberapa produk, biasanya para pemula itu kemudian dengan mengendarai bis ke Bali untuk melemparkan produknya. Setelah mendapat kepercayaan, biasanya mereka tinggal mengirimkan barang, dan uang diperoleh dengan ditransfer pada rekening mereka. Cukup sederhana.

Gapura Troso juga menjadi indikator perkembangan tenun Troso. Dengan alat ATBM yang dimiliki sejumlah 70 unit, tenaga kerja yang dimiliki LIMA PUTRA kurang lebih sejumlah 80 orang. Hampir seluruh tenaga kerja di tempat ini adalah tetangganya sendiri. Masing-masing tenaga kerja itu memiliki spesifikasi sendiri-sendiri di dalam pekerjaannya. Ada yang tugasnya ngelos benang, menggambar, mengikat, mewarnai, hingga menenun. Biasanya proses produksi khususnya menenun dibawa pulang oleh masing-masing pegawainya. Setelah akhir minggu, yaitu hari Kamis karena di Jepara, pekerjaan satu minggu diakhiri pada hari Kamis, karena hari Jum'at mereka libur. Sedangkan hari Minggu mereka justru bekerja. Hal ini mencerminkan tingkat religiusitas mereka yang tinggi, menghormati hari Jum'at sebagai hari besar umat Islam, maka sejak mulai sesudah waktu Asar biasanya mereka berbondong-bondong menyetorkan hasil pekerjaannya sekaligus meminta upah atas hasil kerjanya. Biasanya setiap minggu para penenun itu bisa menenun 6 hingga 7 potong kain bermotif, masing-masing dengan panjang 2,5 m.

Sedangkan jika kain polos akan lebih cepat dibuat, yaitu $10 \mathrm{~m}$ per hari. Untuk harga upah tergantung dari jenis kerumitan motif. Untuk jenis kain super yang harganya Rp. 400.000,- per meter, H. Sairin memberikan upah Rp. 80.000,- per potong kain. Untuk kain bermotif biasanya ongkosnya Rp. 50.000,- untuk penenun lakilaki, dan Rp. 30.000,- untuk penenun wanita. Sedangkan untuk sutra, upah tergantung dari kehalusan hasil tenun. Ada empat varian harga upah sutra, yaitu Rp. 25.000,-; Rp. 40.000,-; Rp. 60.000,- dan Rp. 70.000,-. Hasil kerja para pegawai terutama dalam menenun biasanya disetorkan para pegawai pada hari Kamis sore sebagai dasar untuk minta upah. 


\section{HASIL DAN PEMBAHASAN}

\section{Konsep Gapura debagai Desain Komunikasi Visual Tenun Troso Jepara.}

Gapura juga menjadi Brand desa Troso sebagai ikon pintu masuk desa Troso. Keberadaan setiap brand adalah unik dan mempunyai perbedaan satu dengan yang lainnya. Brand hadir karena mereka sengaja diciptakan untuk memenuhi kebutuhan audiensnya. Proses kehadiran brand inilah yang disebut branding, karena branding bukan hanya berbicara mengenai market share saja, tetapi juga berbicara mengenai mind dan heart share (Permana, 2012:47). Branding tenun Troso diarahkan pada pengangkatan potensi masyarakat berdasar kebudayaan yang luhur dan telah berumur ratusan tahun. Kebudayaan dapat ditingkatkan menjadi produk kreasi dengan nilai seni tinggu sehingga menjadi produk kreasi yang memiliki nilai ekonomi bagi masyarakat.

Hampir sebagian kebutuhan manusia telah dan dapat dipenuhi dengan menggunakan kebudayaannya, yang berfungsi sebagai pedoman untuk bertindak. Dalam hal ini kebudayaan diartikan sebagai keseluruhan pengetahuan, kepercayaan dan nilai-nilai yang dimiliki oleh manusia sebagai mahluk sosial. Isinya berupa perangkatperangkat model pengetahuan atau sistemsistem makna yang terjalin secara menyeluruh dalam simbol-simbol yang diturunkan dari satu generasi ke generasi selanjutnya. Setiap kebudayaan umumnya berubah-ubah, terutama apabila ada pengaruh dari luar tafsir historik dapat ditelaah kebudayaan diwaktu lampau dalam pertumbuhan dan perkembangan dari masa ke masa (Rizali, 2014:25).

\section{Strategi komunikasi visual brand Tenun di Desa Troso Jepara setelah adanya Gapura}

Strategi Komunikasi Visual Brand Tenun Troso banyak terlihat dari tampilan Gapura Tenun Troso. Gapura adalah bangunan penanda atau simbol suatu lokasi. Biasanya Gapura ini bentuknya berada di sisi kiri dan kanan jalan masuk atau melingkari jalan. Di Desa Troso sebagai penghasil industri tenun, telah memiliki Gapura pintu masuk yang berada di jalan masuk desa Troso yang merupakan jalan Propinsi dari kecamatan pecangaan menuju kecamatan kedung atau desa Bugel menuju kota Jepara. Pada zaman kolonial, jalan ini merupakan jalan utama menuju kota Jepara, akan tetapi setelah tahun 1960 dibuat jalan dari kecamatan Pecangaan menuju kecamatan Tahunan sebagai sentra furniture menuju kabupaten Jepara. Gapura ini dipinggir jalan besar yang menghubungkan antara Pecangaan dengan Jepara melalui Jalur dalam.

Seperti halnya tanda maupun simbol, bentuk berfungsi sebagai ekspresi serta memberikan makna dan pemahaman melalui suatu penafsiran. Oleh karena itu bentuk rupa merupakan simbol ekspresi yang mengungkapkan ide dan perasaan. Bentuk rupa seringkali memiliki makna mendalam, yaitu suatu konsep yang paling bernilai dalam kehidupan masyarakat. Jenis simbol ekspresi seperti bentuk rupa jumlahnya lebih banyak dibandingkan dengan jenis simbol lainnya, yaitu simbol kontruksi, evaluasi dan kognisi (Rizali, 2014:36). 
Simbol Gapura tenun Troso dapat dijadikan sebagai strategi komunikasi visual untuk menunjukkan karya produk tenun kepada wisatawan yang datang ke desa Troso. Gapura pintu masuk ditunjukkan dengan dua pilar besar di sisi kiri dan kanan jalan dengan gambar tenun Troso, sementara di atas Jalan berbentuk melengkung dipasang tulisan, "Selamat Datang Di Desa Atraksi Wisata Tenun Troso"

Strategi komunikasi merupakan panduan dari perencanaan komunikasi dan manajemen untuk mencapai suatu tujuan. Untuk mencapai tujuan tersebut strategi komunikasi harus dapat menunjukan bagaimana operasionalnya secara taktis harus dilakukan, dalam arti kata bahwa pendekatan (approach) bisa berbeda sewaktu-waktu tergantung dari situasi dan kondisi, (Effendy, 2003:34). Sedangkan Komunikasi pemasaran terpadu (IMC) adalah proses pengembangan dan impementasi berbagai bentuk program komunikasi persuasif kepada pelanggan dan calon pelanggan secara berkelanjutan. Tujuan IMC mempengaruhi atau memberi efek langsung kepada perilaku khalayak sasaran yang dimilikinya. IMC menganggap seluruh sumber yang dapat menghubungkan pelanggan atau calon pelanggan dengan produk atau jasa dari suatu merek atau perusahaan, adalah jalur yang potensial untuk menyampaikan pesan di masa datang. Lebih jauh lagi, IMC menggunakan semua bentuk komunikasi yang relevan serta yang dapat diterima oleh pelanggan dan calon pelanggan, kemudian berbalik kepada perusahaan untuk menentukan dan mendefinisikan bentuk dan metode yang perlu dikembangkan bagi program komunikasi yang persuasif (Shimp. 2003:25).
Dari gapura tenun Troso masuk kurang lebi 500 meter, para pengunjung akan disuguhi berbagai showroom hingga menuju desa sowan sepanjang $2 \mathrm{Km}$. Para wisatawan dapat memenuhi hasrat untuk membeli produk tenun Troso tanpa harus mengunjungi satu persatu pengrajin Troso. Dahulu sebelum munculnya showroom, para wisatawan atau pembeli dari luar kota mengalami kesulitan menemukan tempat yang menjual produk tenun. Mereka harus bertanya kepada penduduk, untuk menemukan tenun terhambat dan pengrajin juga tidak mampu menjual produk tenun dalam waktu singkat. Dampak yang lain adalah sirkulasi modal menjadi terhambat.

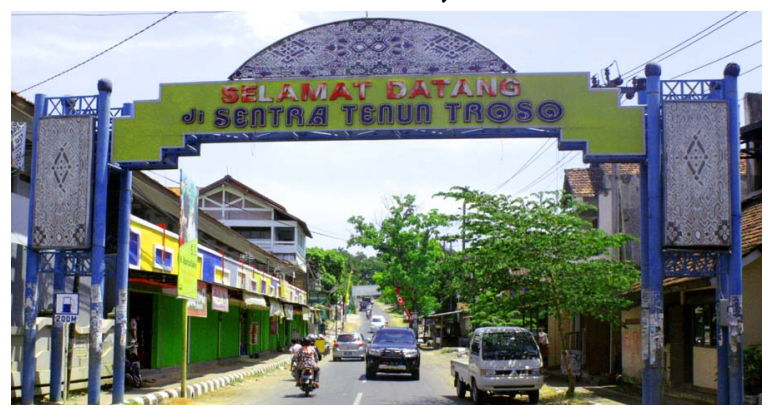

Gambar 2 Gapura Tenun Troso Sumber: Foto Wijanarko (6/7/2017)

Eksistensi Gapura sangat membantu sebagai penanda para wisatawan untuk masuk ke desa Troso. Gapura menjadi tempat jujukan bagi para pembeli dan wisatawan baik domestik maupun manca negara untuk masuk melihat atraksi wisata tenun Troso. Setelah melewati gapura, para wisatawan dapat masuk ke setiap showroom pengusa tenun yang ada di desa Troso Melalui media showroom pengrajin dan pengusaha semakin kreatif dalam dalam membuat desain dan berbagai jenis produk. Di showroom ini banyak sekali dipajang berbagai jenis produk mulai dari kain tenun ikat dengan berbagai motif, kain lurik, kain polosan warna-warni, 
kain tenun dibatik, kain baju tree in one (sarung, selendang, baju), kain sarimbit (untuk suami istri), sarung dan selendang (satu stel untuk busana wanita), sarung, sajadah, berbagai jenis dan ukuran syal baik untuk pria maupun wanita, berbagai jenis kerudung, selendang sutra, berbagai jenis perlengkapan rumah tangga, seperti:kain selimut dengan berbagai motif dan ukuran, kain korden, taplak meja satu set dengan bantalan kursi, taplak dari akar wangi, baik ukuran besar untuk meja tamu maupun kecil untuk meja telpon, taplak dari lidi, baik ukuran besar untuk, meja tamu maupun kecil untuk meja telpon, hiasan dinding dari lidi, berbagai jenis dan ukuran sarung bantal, tempat tissue, tempat magic com, kasur, bantal, dan produk yang lain.

Dengan tampilan Gapura yang baik, pengembangan industri pariwista kerajinan di Jepara, terutama tenun Troso mempunyai masa depan yang cerah, mengingat banyak potensinya yang ada. Industri pariwisata tidak perlu mendatangkan mesin- mesin atau teknologi canggih lainnya sebagai penunjang. Di samping itu produksi pariwisata tidak perlu diditsribusikan dengan alat angkut yang memerlukan pembiayaan sarana serta prasarana transportasi dan komunikasi. Indusrti pariwisata hanya membutuhkan promosi untuk memperkenalkan kepada masyarakat luas daya tarik produk dan potensi yang terkandung di dalamnya. Salah satu promosi bagi Tenun Troso adalah keberadaan Gapura.

\section{KESIMPULAN}

Gapura sebagai desain komunikasi visual tenun Troso Kabupaten Jepara digunakan sebagai penanda pintu masuk ke desa Troso. Gapura Tenun Troso terletak di pinggir jalan besar yang menghubungkan antara Pecangaan dengan Jepara melalui Jalur dalam. Setelah melewati Gapura kurang lebih 500 meter, banyak sekali produk tenun yang dipajang untuk dipasarkan melalui media showroom.

Dengan tampilan Gapura yang baik, pengembangan industri pariwista kerajinan di Jepara, terutama tenun Troso mempunyai masa depan yang cerah, mengingat banyak potensinya yang ada.

Hasil Penelitian ini berimplikasi dan bermanfaat dapat memperkaya wawasan konsep wisata dan menjadi referensi kajian seni rupa terutama tentang Gapura tenun Troso. Semoga hasil penelitian ini dapat menjadi rujukan bagi penelitian selanjutnya, menambah referensi seni rupa tentang gapura dalam pengembangan wisata desa.

Semoga hasil penelitian ini dapat memberikan informasi bagi wisatawan untuk masuk ke desa Troso dengan melalui Gapura yang ada. Bagi pemerintah daerah semoga dapat memberikan bantuan dengan pembuatan Gapura di sebelah Barat desa Troso yakni pada perbatasan desa Troso dengan desa Ngeling kecamatan Pecangaan Jepara.

\section{KEPUSTAKAAN}

\section{Artikel Jurnal}

[1] Adhityo Nugroho. 2014. Slogan Solo The Spirit Of Java Sebagai Promosi Pemerintah Kota Solo Untuk Go International (Implementasi Penggunaan Slogan "Solo, The Spirit of Java" dalam Strategi City Branding Kota Solo Melalui Penyelenggaraan Event Kebudayaan 
Tahun 2012). Program Studi Ilmu Komunikasi Fakultas Ilmu Sosial Dan Ilmu Politik Universitas Negeri Sebelas Maret Surakarta.

[2] Karta, Ni Luh Putu Agustini dan Suarthana I Ketut Putra. 2014. Strategi Komunikasi Pemasaran Ekowisata Pada Destinasi Wisata Dolphin Hunting Lovina. Jurnal Manajemen Strategi Bisnis dan Kewirausahaan Vol.8 No.1, Februari 2014.

[3] Muchamad Saiful Anam, Daniar Wikan Setyanto, Dzuha Hening Yanuarsari. 2014. Perancangan Visual Branding Kabupaten Kudus Sebagai Upaya Promosi Kabupaten. Jurusan Desain Komunikasi Visual, Fakultas Ilmu Komputer, Universitas Dian Nuswantoro. Semarang.

\section{Buku}

[1] Arifin, Zaenal. 2013. Strategi Komunikasi Sebuah Pengantar Ringkas, Armico. Bandung.

[2] Arikunto, Suharsimi. 2005. Prosedur Penelitian, PT Renika Cipta. Jakarta.

[3] Efendy. 2007. StrategiPemasaran, Erlangga. Bandung.

[4] Hassan Shadily. 2002. Ichtiar Baru-Van Hoeve. Gramedia. Jakarta.

[5] Kasali, Rhenald. 2007. Membidik Pasar Indonesia; Segmentasi, Targeting, Positioning. PT. Gramedia Pusaka Utama, Jakarta.

[6] Kusmiati, A, S. Pudjiastuti \& P. Suptandar. 1999. Teori Dasar Desain Komunikasi Visual. Djambatan. Jakarta.

[7] Moleong. Lexy J. 2005. Metodologi Penelitian Kualitatif. Remadja Karya. Bandung

[8] Rizali, Nanang. 2014. Nafas Islam Dalam Batik Nusantara. UNS Press. Surakarta.
[9] Sachari, Agus. 2003. Paradigma Desain Indonesia. CV Rajawali. Jakarta.

[10] Shimp, Terence A. 2003. Periklanan dan Promosi, Aspek Tambahan Komunikasi Pemasaran Terpadu. Erlangga. Jakarta.

[11] Sugiyono. 2009. Metodologi Penelitian. Alfabeta. Bandung.

[12] Tjiptono, Fandi. 2003, Strategi Pemasaanr, Andi, Yogyakarta.

[13] Umar, Husein. 2002. Riset Sumber Daya Manusia dalam Organisasi. PT. Gramedia Pustaka Utama. Jakarta.

[14] Widagdo.1993. "Desain, Teori, dan Praktek", Seni Jurnal Pengetahuan dan Penciptaan Seni. BP ISI Yogyakarta III/03 1993. 15-31.

[15] World Bank, 2001. Kualitas pertumbuhan. Gramedia Pustaka Utama, Jakarta.

\section{Bunga Rampai}

[1] JICA, 2004. Final Reports of the Study on Strengthening Capacity of SME Clusters in Indonesia, Japan International Cooperation Agency.

[2] Badan Pusat Statistik Kabupaten Jepara, 2017, Jepara dalam angka, http/BPSjepara.go.id 